\title{
Aikuiskasvatuksen käytäntö ja teoria
}

Seuraaviin mietteisiin antoi virikkeen Aulis Alasen juuri ilmestynyt kirja Johdatus aikuiskasvatukseen (Yleisradio).

Aikuiskasvatuksen käytäntöön liittyy aina teoria. Tähän teoriaan kuuluu väistämättömästi käsitys aikuiskasvatuksen tavoitteesta, siihen vievästä menetelmästä ja tavoitteen saavutettavuudesta.

Sitä mukaa kuin ei enää tyydytä aikuiskasvatuksesta olevaan arkikokemukseen, vaan siitä ryhdytään hankkimaan tietoa tieteellisin menetelmin, syntyy tieteellistä teoriaa, aikuiskasvatustiedettä.

\section{Aikuiskasvatuksen kehitysvaiheita}

1800-luvun loppupuoliskolla ruvettiin maassamme harjoittamaan vapaata kansanvalistustyötä. Sen teoriana oli valistusfilos ofia, jonka mukaan tiedon valon levittäminen kansan keskuuteen oli hyödyllistä. Menetelmänä olivat luento ja kansantajuisen kirjallisuuden tuottaminen. Vallitsi vahva optimistinen usko, että kansa voidaan valistaa.

Valistustyön kohderyhmä oli koulusivistystä vailla oleva sivistymätön sääty eli rahvas. Atribuutilla "vapaa" ilmaistiin muun muassa, että kohteena ovat aikuiset. Alanen ei tätä sano.

Alasen mukaan seuraava kehitysvaihe, vapaan aikuiskasvatuksen kausi, ajoittuu suunnilleen ensimmäistä maailmansotaa seuranneista vuosikymmenistä 1960-luvulle asti.

Sanoisin asian toisin, nimittäin näin: Vapaan kansanvalistustyön kausi rupesi vähitellen muutumaan vapaan kansansivistystyön kaudeksi tämän vuosisadan toisen vuosikymmenen paikkeilla.

En tiedä, milloin termi vapaa kansansivistystyö syntyi ja kenen toimesta. Ilmeisesti se luotiin vastineeksi saksan ilmaisulle die freie Volksbildungsarbeit tai ruotsin det fria folkbildningsarbetet. Joka tapauksessa sen vakiin- nutti yleiseen käyttöön Castrén. Hän selitti myös, että sen sisältö on laajempi kuin vapáan kansanvalistystyön, joka rajoittuu vain ihmisen tietopuoliseen kehittämiseen.

Miksi Alanen käyttää ainakin minulle tuntematonta nimitystä vapaa aikuiskasvatus? Mikä olisi sen vastakohta?

Alanen toteaa, että termi aikuiskasvatus tuli käyttöön 1940-luvulla ja että sen käyttö vähitellen yleistyi tultaessa 60 -luvulla, jolloin astui näyttämölle uusi termi aikuiskoulutus.

Yhdyn siihen, mitä Alanen näiden käsitteiden merkityksestä sanoo. Viittaan lisäksi seuraavaan seikkaan.

Meillä on ties kuinka kauan puhuttu ammattisivistyksestä ja ammattikasvatuksesta. Meillä on edelleenkin ammattikasvatushallitus. Miksi on pitänyt ruveta puhumaan aikuisten ammatillisesta koulutuksesta? Miksei sovi puhua aikuisten ammattikasvatuksesta? Onko tarkoitus julistaa, että pelkkă ammattitaito, ammatin tekninen osaaminen riitää?

Ainakin ulkomailla korostetaan, että ammattikasvatuksen pitää kuulua myös yleissivistävää ainesta.

Minusta aikuiskoulutus on turha sana. Se ei ilmaise mitään sellaista, mită ei voida ilmaista mukavasti perinteisin käsittein. Kuten Alanenkin toteaa sana aikuiskoulutus vain sotkee käsitteistöä.

Kun kerroin Viljo Tarkiaiselle, että Yhteiskunnallisessa Korkeakoulussa olevan kansansivistysopin nimi aiotaan muuttaa aikuiskasvatukseksi, hän ei tätä hyväksynyt. Syynä ei kuitenkaan ollut se, että hänen mielestään ei voitaisi puhua aikuisten kasvattamisesta, millä perusteella muun muassa T. I. Wuorenrinne vastusti uutta nimeä. Tarkiainen hyvăksyi tăysin aikuiskasvatuksen idean, mutta hän korosti, että kansansivistysoppi on alaltaan paljon laajempi kuin aikuiskasvatusoppi. Kansansivistysopin supistaminen aikuiskasvatusopiksi olisi hänen mielestään valitettavaa.

Vasta Alasen kirjaa lukiessani rupesin vaka- 
vasti miettimään Tarkiaisien kritiikkiä. Olen myös uusin silmin luken Castrénin kuuluisan vapaan sivistystyön määritelmän.

Palaan tähän tarkasteltuani ensin Alasen ajatuksia.

\section{Eriytynyt ja eriytymätön aikuiskasvatus}

Eriytymätöntä aikuiskasvatusta harjoittavat Alasen mukaan mm. yleiset kirjastot, sanomalehdet, kirjankustantajat sekä radio ja televisio. Ne harjoittavat sitä kuitenkin vain "sikäli kuin ne pyrkivät objektiiviseen tiedon välittämiseen ja herättämään yleisössään itsenäistä ja kriittistä ajattelua."

On myös ei-kasvatuksellista vaikuttamispyrkimystä, kuten uskonnollista ja poliittista käännyttämistä sekä monenlaista propagandaa.

Tarkiainen tarkoitti, että kansansivistysopin tuli tarkastella - Alasen termejä käyttäen sekä eriytynyttä että eriytymätöntä aikuiskasvatusta.

Tämä oli myös Castrénin käsitys: "Vapaaksi kansansivistystyöksi sanotaan kaikkea sitä moninaista tointa, jonka tarkoituksena on saada hereille ja edistää aikuisten vapaita itsekasvatuspyrkimyksiä'. On selvää, että Castrénin mukaan kansansivistysopin kohteena ei ole vain eriytynyt aikuiskasvatus, varsinainen aikuiskasvatus.

Verrattakoon Castrénin määritelmään Alasen määritelmäă: "Aikuiskasvatus on organisoitua toimintaa, jonka avulla aikuiset voivat normaalimuotoisen kouluopetuksen ulkopuolella toteuttaa tavoitteisesti etenevää oppimista..."

Alasen määritelmän mukaan aikuiskasvatuksen ala on suppeampi kuin kansansivistysopin.

Hän huomauttaa kuitenkin, että varsinaisen aikuiskasvatuksen kannalta on tärkeätä ottaa huomioon myös ne kasvatukselliset vaikutukset, joita aikuisiin suuntautuu eriytyneen opintotoiminnan ulkopuolelta. Ei-kasvatuksellisista vaikuttamisyrityksistä hän ei sano mitään.

Palaan tähän asiaan myöhemmin.

\section{Kansansivistysopin ala}

Minulla ei ole juuri mităän tietoa siitä, miten Castrén käsitti kansansivistysopin alan ollessaan tămăn aineen opettajana YKK:ssa. Tătä kirjoittaessani minulla ei ole kăytettăvănä edes kansansivistysopin kurssivaatimuksia. Sen kuitenkin muistan, ettă tullessani tămän aineen si- vutoimiseksi opettajaksi 1940 eli pari vuotta Castrénin jälkeen kurssivaatimuksissa oli muutakin kirjallisuutta kuin varsinaista aikuiskasvatusta koskevaa. Tämän alan sekä kotimaista että ulkomaista kirjallisuutta olikin niin vähän, ettei olisikaan voinut rajoittua pelkästään siihen. Mutta uudistaessani kurssivaatimuksia otin tahallani mukaan varsinaisesta aikuiskasvatuksesta kaukana olevaa kirjallisuutta. Esimerkkinä olkoon Niilo Söyringin 1954 ilmestynyt Luonnonsuojelun käsikirja. Pidin jo tuolloin luonnonsuojelua niin tärkeänä asiana, että mielestäni aikuiskasvattajienkin piti siihen tutustua.

On tietenkin vähän eria asia, mitä kansansivistysopin tai aikuiskasvatustieteen alaan katsotaan kuuluvan ja minkälaisia tietoja aikuiskasvattajaksi valmistuvan katsotaan tarvitsevan.

\section{Aikuiskasvatus ja arvokritiikki}

Aikuiskasvatukseen sisältyy väistämättömästi arvostuksia. Ennen kaikkea asetettaessa tavoitteita joudutaan ottamaan kantaa arvoihin joko eksplisiittisesti tai implisiittisesti. Kannanotolta eivät voi väistyä sen paremmin opiskelijat kuin opettajatkaan.

Toisinaan aikuiskasvatuksessa on asetuttu jyrkästikin vastustamaan joitakin yleisesti vallitsevia arvoja. Alasen mukaan juuri nyt eletään tällaista arvokritiikin kautta. Vaaditaan, että aikuiskasvatuksen on ryhdyttävă vastustamaan esim. niitä arvoja, joihin taloudellisen kasvun ideologia ja kaupallinen massakulttuuri perustuvat.

Entä miten aikuiskasvatustieteen pitää suhtautua arvokysymyksiin? Olen ankarasti positiivisen tiedekäsityksen kannalla, jonka mukaan aikuiskasvatustieteenkin, vaikka se onkin käytännöllinen tiede, on oltava arvovapaata.

Teen kuitenkin jyrkän eron tutkijan ja tieteen välillä. En sano Alasen tapaan, että tiede tulee arvosidonnaiseksi sen kautta, että tutkija tekee aina arvovalintoja. Vaikka esim. tutkimuskohteen valinta on aina arvoratkaisu, ei tutkimus saa sisältää mitään arvostuksia tai ohjeita.

Aikuiskasvatuksen tutkijan pitää mielestäni suorittaa arvoratkaisuja sen takia, että aikuiskasvatus on käytännöllinen tiede. Alanen on oikeassa sanoessaan, että arvoratkaisuja voidaan myös perustella. Niitä voidaan perustella filosofisin argumentein ja myös tieteen tuloksiin vetoamalla, mutta mitään arvoratkaisua ei voida loppuun saakka perustella pelkästään 
tieteellisin menetelmin.

Tutkijan etiikkaan mielestäni kuuluu, että hän ilmaisee selvästi, mikä hänen kirjoituksissaan on puhdasta tiedettä, esim. empiirisen tutkimuksen tuloksia, mikä taas on arvopitoista puhetta.

Nyt voinkin palata siihen Alasen huomautukseen, että on tärkeätä sttaa huomioon myös varsinaisen aikuiskasvatuksen ulkopuolelta aikuisiin tulevat kasvatukselliset vaikutukset.

Minun mielestäni aikuiskasvatuksen tutkijan on otettava huomioon ja tutkittava kaikkia niitä tekijöitä, niin kasvatuksellisia kuin eikasvatuksellisiakin, jotka vaikuttavat positiivisesti tai negatiivisesti aikuisten sivistykseen tai itsekasvatuspyrkimyksiin. Sanon näin siksi, että olen omaksunut kreikkalaisen paideiaajatuksen. Sen mukaan yksittäinen kasvattaja eikä myös kasvatusinstituutio yksinään voi saada paljonkaan aikaan. Siksi kaikkien sosiaalisten instituutioiden on yhdessä kannettava vastuuta kasvatuksesta.

Kaikkien kasvattajien pitäisi kritikoida yhteiskuntaa ja kulttuuria kasvatuksen näkökulmasta silmämääränä niiden muuttaminen kasvatukselle suotuisaksi. Aikuiskasvatuksen tutkijan on tehtävä tämä aikuiskasvatuksen kannalta.

Tällainen "elämän pedagogisoiminen", tekeminen kasvatukselle suotuisaksi, on tietenkin kovin vaikeata, jopa osittain mahdotontakin. En usko, että esim. Bildung durch Arbeit, kulkeminen sivistykseen työn avulla, voisi täysin toteutua. On kylläkin mahdollista jossakin määrin humanisoida työtä, muovata sitä nykyistä paremmin vastaamaan kasvatuksen intressejä, mutta luullakseni työ ei koskaan voi täysin muuttua ihmistä ruumiillisesti ja henkisesti kehittäväksi. Tämä oli myös Marxin käsitys. Mutta kannattaa pyrkiä saavuttamattomiinkin ideaaleihin.

\section{Liberalismi ja aikuiskasvatus}

Liberalismi on aikuiskasvatukseen voimakkaasti vaikuttanut aate. Tämä on tavallaan yllättävää, sillä liberalismi ei ole saanut Suomessa paljonkaan kannatusta lukuunottamatta ruotsinkielistä sivistyneistöä. Kuvaavaa on, että liberaalinen kansanpuolue riutui.

Liberalismin heikkous ilmenee myös siinä, että uskonnonvapauden tultua voimaan 1922 se toteutettiin sangen puutteellisesti. Niinpä tunnustuksellinen uskonnonopetus jäi kou- luun kirkon tahdosta ja on säilynyt tähän päivään saakka.

Alanen mainitsee, että vapaan sivistystyơn perinteessä on ennen muita erottuneet liberalistinen, kristilliinen ja marxilainen pääsuuntaus.

Liberalismi ei ilmene kuitenkaan vain liberalistisessa suuntauksessa, vaan myös näiden suuntausten keskinäisissä suhteissa. Kun rupesi syntymään kristillisiä kansanopistoja, grundtvigilaisten opistojen taholta väitettiin, etteivät ne ole mitään kansanopistoja. Sangen pian ne kuitenkin hyväksyttiin jäseniksi Kansanopistoyhdistykseen ja oikeutetuiksi valtionapuun. Tähän vaikutti Castrén, joka tähdensi, että kansansivistystyötä pitää saada harjoittaa erilaisissa "'henkisissä ilmapiireissä"'.

Vastaavasti kristillishenkiset työväenopistot on hyväksytty liberalisisten työväenopistojen joukkoon.

Työväenopistomme syntyivät Tukholman työväenopiston toimiessa esikuvana Comten positivistisessa hengessä, joka oli voimakkaasti uskonnonvastainen. Näin ollen on ymmärrettävää, että uskontoa ei hyväksytty työväenopiston oppiaineeksi ja että Helsingin työväenopistoon vaadittiin ateismin opetusta.

Turun työväenopiston ohjesääntö hyväksyttiin vasta kun opetusaineiden joukosta oli poistettu uskonnonhistoria ja tilalle pantu siveysoppi.

Pian työväenopistojen yleiseksi aatesuunnaksi vakiintui liberalismi. Se ei hyväksy työväenopistoliikkeen aatepohjaksi ateismia eikä myöskään uskontoa, mutta opistoissa voidaan käsitellä kumpaakin kunhan se tapahtuu tieteenomaisessa hengessä.

Minusta on toivottavaa, että liberalismi aikuiskasvatuksessa säilyisi ja vahvistuisi, koska se on humanismin hengen mukaista.

\section{Humanismi ja aikuiskasvatus}

Humanismi on laajasti ja syvästi aikuiskasvatukseen vaikuttanut aate. Kuvaavaa on, että kun kansansivistysopin opiskelijat päättivăt perustaa aineyhdistyksen ja pohtivat sille annettavaa nimeä valittiin nimeksi yksimielisesti Paideia.

Viimeaikaisessa keskustelussa aikuiskasvatuksen ihmiskäsityksestä on voimakkaasti korostettu humanistista käsitystä.

Alanen mainitsee humanismin vain yhdessä kohdassa, mutta ottaa siihen myönteisen kannan. Hän sanoo, että humanistinen kasvatusnäkemys voidaan ja tulisi ulottaa myös amma- 
tilliseen aikuiskoulutukseen ja työelämään.

Humanismi tulisi ottaa huomioon aikuiskasvatuksessa kahdella tavalla. Ensinnäkin olisi pyrittävä herättämään opiskelijoissa humanistinen elämänkatsomus ja sitä kehittämään. Tämä edellyttää tietenkin sen tutkiskelua, millainen humanistinen elämänkatsomus on. Esim. mitkä ovat humanistisia arvoja ja mitkä epäarvoja.

Toiseksi olisi pohdittava, mitä humanismin toteuttaminen merkitsee nykyhetken ja tulevaisuuden yhteiskunnassa: työelämässä, talouselämässä, tekniikassa, sosiaalipolitiikassa, suhtautumisessa luontoon jne.

\section{Sivistys ja tasavertaisuus}

Aikuiskasvatus ei tule toimeen ilman sivistyksen käsitettä ja-teoriaa.

Yleiset kirjastot luettiin alunperin vapaan kansansivistystyön piiriin. Niitä käsiteltiin YKK:n kansansivistysopissa.

Alanen pitää yleisten kirjastojen toimintaa eriytymättömänä aikuiskasvatuksena. Ne suorittavat kulttuuripalvelua, jolle on asetettu sivistystehtäviä, jotka ovat ainakin väljästi tulkiten intentionaalisesti kasvattavia.

Kirjastoasetuksen mukaan "yleisten kirjastojen tarkoituksena on kirjastolaitokselle ominaisin toimintamuodoin tyydyttää yleistä sivistystarvetta ja lukuharrastusta."

Olen osoittanut, että kirjastotiede sikäli kuin se koskee yleisiä kirjastoja on vaarassa luisua vähämerkityksiseeksi tai suorastaan nollatutkimukseksi ellei selvitetä kirjaston tarkoitusta, mikä vaatiii jonkin sivistysteorian omaksumista (Kirjastotiede ja sivistysteoria. Aikuiskasvatus 4/83). Tämän teorian on oltava sellainen, että sen puitteisiin voidaan puhua mielekkäästi $\mathrm{mm}$. yleisestä sivistystarpeesta.

Sekä aikuiskasvatustiede että kirjastotiede tarvitsee sivistysteorian. Riittääkö, että aikuiskasvatustiede luo sen yksin vai tarvitaanko kummankin tieteen yhteistyötä ja vuorovaikutusta?

Kun Yleisradio perustettiin 1925 sen päämääristä mainittiin ensimmäisenä "kansansivistystyön edistäminen". Myöhemminkin on korostettu sen sivistys- ja kasvatustehtävää. Vuonna 1967 julkaistussa ohjelmapoliittisessa suunnitelmassa pidetään aikuiskasvatusta Yleisradion yhtenä keskeisenä tehtävänä.

Jos näin on tälläkin haavaa tarvitsee myös radio- ja televisiotiede sivistysteorian. Kenen tehtävä on sen luominen?

Mainittu suunnitelma oli altis kovallekin kritiikille. Olen silloin tällöin korostanut, että
Yleisradion pitäisi selvittää minkälaiseen sivistysteoriaan sen toiminta pohjautuu. Yleisradion ohjelmatoiminnan asiallinen kritikoiminen on oikeastaan mahdotonta ellei tiedetä, minkälaiseen sivistysteoriaan se perustuu.

Tasavertaisuuden idea on valtavasti mullistanut yhteiskuntaa ja sivistyselämää. Sen nimissä ruvettiin arvostelemaan muun muassa rinnakkaiskoulujärjestelmää, koska siinä oli eri yhteiskuntaluokkien lapsille erilainen koulu. Vapaa kansansivistystyö ei ole koskaan ollut tällä tavalla kaksijakoinen, joten kritiikki ei kohdistunut siihen.

Vaikka aikuiskasvatusinstituutioiden ovet ovat tasavertaisesti avoinna kaikille, on käynyt ilmi, että eri yhteiskuntaluokkien jäsenet eivät astu niistä sisään tasavertaisesti. Siksi on ruvettu vaatimaan sellaisia toimenpiteitä, että tasavertaisuus saavutettaisiin.

Alanen kirjoittaa sivistyksellisestä tasavertaisuudesta tavalla, jota vastaan minulla ei ole huomauttamista. Mielestäni hänen olisi kuitenkin pitänyt sanoa, mitä hän tarkoittaa objektiivisella oppimistarpeella.

Yhteen seikkaan tahdon kuitenkin kiinnittää huomiota. Alanen toteaa, että ne toimenpiteet, joiden avulla aikuiskasvatuksen piiriin on yritetty vetää vähän koulutusta saaneita ja sivistyksellisesti huono-osaisia, ovat menestyneet heikonlaisesti. Tämä on minusta ymmärrettävää. Viitaten siihen, mitä sanoin jaksossa 4, väitän että pelkästään aikuiskasvatuspoliittisiin toimenpiteisiin ei voida päästä sivistykselliseen tasavertaisuuteen. Tarvitaan myös sosiaalipoliittisia toimenpiteitä, joten aikuiskasvatuspolitiikan ja sosiaalipolitiikan on kuljettava käsi kädessä.

\section{Aikuiskasvatus tiedejärjestelmässä}

Kysymys, mikä on aikuiskasvatustieteen asema tieteiden järjestelmässä, ei ole minua kiinnostanut, koska pidän sitä elävän elämän kannalta steriilinä. Sen sijaan minusta on tärkeätä pohtia, miktä tieteet ovat aikuiskasvatukselle tärkeitä. Yhdyn Alasen käsitykseen, että tällaisia tieteitä ovat filosofia, psykologia, sosiaalipsykologia, sosiologia ja historia, mutta lisäisin biologian.

Minusta Tampereen yliopisto on sopiva paikka aikuiskasvattajien ja aikuiskasvatuksen tutkijoiden valmistamiseen sekä aikuiskasvatuksen tutkimuksen harjoittamiseen, koska seillä on aikuiskasvatuksen kannalta tärkeitä tieteitä mm. kirjastotiede sekä radio- ja televisio-oppi. Sieltä kuitenkin puuttuu käy- 
tännöllisen filosofian professuuri, joka sopisi yhteiskuntatieteelliseen tiedekuntaan. Olen esittänyt myös sellaisen käsityksen, että tässä tiedekunnassa pitäisi olla sosiobiologian professuuri. Tarkoitan sillä tiedettä, joka tutkii biologisten ilmiöiden vaikutusta yhteiskuntaan, mm. kasvatukseen.

Meillä on jo pitkään vallinnut käsitys, että aikuiskasvatus kuuluu kasvatustieteisiin tai kasvatustieteen osa-alue. Mutta mikä on sitten kasvatustieteen asema tieteiden järjestelmässä?

Alanen jakaa empiiriset tieteet luonnontieteisiin ja ihmistieteisiin sekä viimeksimainitut humanistisiin ja yhteiskuntatieteisiin. Kasvatustieteet kuuluvat jälkimmäisiin.

Alasen käsitys, että "kasvatustieteet ovat perusluonteeltaan yhteiskuntatieteitä perustuu kasvatuskäytännön yhteiskunnallisuuteen." Hän vetoaa Durkheimiin selittäessään, että tietoinen kasvatus on suunnitelmallista sosiaalistamista, "jolloin kasvatustiede määrittyy kohteensa mukaan sosiaalistamista tutkivaksi tieteeksi." Alasen mukaan "aikuiskasvatus on kokonaisuutena perusluonteeltaan aikuisuudessa jatkuvaa sosiaalisaatiota".

Mielestäni kasvatus on sosiaalisena ilmiönä ja sosiologian näkökulmasta sosiaalistamista eli sosialisaatiota. Olen Systemaattisessa kasvatustieteessä väittänyt, että kasvatus ei ole vain sosialisaatiota, vaan myös personalisaatiota, ihmisen herättämistä itsetajuisuuteen, minätietoisuuteen.

Onko näin todella laita riippuu siitä, minkälainen filosofinen antropologia ja ontologia omaksutaan. Marxilaisen filosofian mukaan ihminen on vain sosiaalinen olento, "yhteiskunnallisten suhteiden kooste (Ensamble)"'.

Kuten olen kirjoissani Moraali ja yhteiskunta sekä Yksilö ja yhteisö osoittanut Durkheim on mitä jyrkin organismiteorian kannattaja. Sen mukaan yhteiskunta on elävä ja tajuinen olento. Ihmisyksilö on vain sen epäitsenäinen jäsen tai solu, joka ei voisi lainkaan olla olemassa ilman yhteiskuntaorganismia. Ontologisesti katsoen siis vain yhteiskunta on todella olemassa, tosiolevaista.

Tällaista käsitystä en hyväksy. Mielestäni yhteiskuntaa ei ole olemassa edellä mainitussa ontologisessa merkityksessä. Yhteiskunta ei ole tajuinen olento, sellainen on vain yksilö. Ihminen ei ole vain sosiaalinen olento, vaan hänessä on myös jotakin yksilöllistä, sosiologisesti selittämätöntä. Viittaan tässä vain Erik Ahlmanin ajatukseen varsinaisest minästä ja Sven Krohnin oppiin ydinihmisestä.

Durkheimin mukaan kasvatus on aikuisen harjoittamaa toimintaa, joka kohdistuu nuoriin.

Mitä nuorempi lapsi on sitä enemmän hänen kasvattamisensa on sosiaalistamista. Aikuiskasvatus on ytimeltään itsekasvatusta. Sekin voi olla sosiaalistamista, mutta sen ei tarvitse olla sitä kokonaan. Aikuiskasvatusta voidaan luonnehtia itsensä todellistamiseksi.

En pidä riittävästi perusteltuna käsitystä, että kasvatustiede kuuluu tieteiden järjestelmässä yhteiskuntatieteisiin. Mutta kuten sanoin, en pidä kysymystä kasvatustieteen paikasta tiedejärjestelmässä tärkeänä. Katselen asiaa käytännön eli yliopiston kannalta kysyen, mihin tiedekuntaan aikuiskasvatuksen opetus ja tutkimus sopii. Mielestäni on hyvä, että yhteiskuntatieteellisen ja humanistisen tiedekunnan rinnalla on kasvatustieteellinen tiedekunta, jossa ovat edustettuina kasvatuksen, siis myös aikuiskasvatuksen tutkimukseen keskittyvät filosofia, historia, mukaan luettuna kasvatustieteen historia, psykologia, sosiologia jne. 